\title{
KINERJA LOGIKA FUZZY SUGENO DALAM MENANGANI PREDIKSI KAIN TENUN DENGAN KOMBINASI RANDOM TREE DALAM MEMBANGUN RULE
}

\author{
Tundo \\ Program Magister Informatika, Universitas Islam Negeri Sunan Kalijaga Yogyakarta \\ Yogyakarta, Indonesia \\ email: asna8mujahid@gmail.com
}

\begin{abstract}
Abstrak
Kain tenun merupakan salah satu produk yang diminati oleh banyak orang. Hal ini menjadi pemicu produsen untuk meningkatkan pengelolahan produksinya. Salah satu usaha yang dilakukan adalah memprediksi produksi yang dapat dilakukan untuk membantu memperkirakan jumlah prosuksi dengan tujuan memberikan gambaran produksi sehingga produsen akan siap menerima segala resiko yang terjadi. Dalam penelitian ini, untuk mendapatkan prediksi jumlah produksi kain tenun dilakukan dengan perhitungan komputerisasi menggunakan metode logika fuzzy Sugeno dengan menggunakan kombinasi pohon keputusan random tree dalam membentuk rule. Kriteria yang digunakan dalam menentukan jumlah produksi yaitu, biaya produksi, permintaan, dan stok yang diperoleh dari pengusaha kain tenun di Mlaki Wanarejan Utara Pemalang. Digunakan pohon keputusan random tree salah satunya untuk membuat rule secara otomatis dari data yang tersedia tanpa perlu berkonsultasi dengan pakar, selain itu untuk memperkenalkan random tree dalam bidang penelitian karena masih sedikitnya penelitian yang menggunakan pohon keputusan ini. Hasil penelitian ini, ditemukan akurasi hasil prediksi yang diujikan memperoleh nilai Average Forecasting Error Rate (AFER) sebesar $42 \%$ dengan nilai kebenaran $58 \%$ setelah dibandingkan dengan data produksi sesungguhnya. Berdasarkan hasil maka perlu dikembangkan kembali agar hasil akurasi yang didapatkan lebih besar lagi, salah satu cara yang dapat dilakukan untuk peneliti berikutnya adalah dengan memperhatikan rule yang terbentuk terutama pada saat dikombinasikan dengan menggunakan orde 0 dan orde 1.
\end{abstract}

Kata kunci: Logika fuzzy, Metode fuzzy Sugeno, Rule, Random tree, Prediksi

\begin{abstract}
Woven fabrics are one of the products that are in demand by many people. This triggers producers to increase their production management. One of the efforts made is to predict the production that can be done to help estimate the amount of production with the aim of providing a picture of production so that producers will be ready to accept all the risks that occur. In this study, to obtain a prediction of the amount of woven fabric production is done by computerized calculations using the Sugeno fuzzy logic method using a combination of random tree decision trees in forming a rule. The criteria used in determining the amount of production, namely, production costs, demand, and stock obtained from woven fabric entrepreneurs in Mlaki Wanarejan Utara Pemalang. Random tree decision trees are used, one of which is to automatically generate rules from the available data without consulting with experts, in addition to introducing random trees in the research field because there are still few studies using this decision tree. The results of this study, it was found that the accuracy of the tested prediction results obtained an Average Forecasting Error Rate (AFER) of $42 \%$ with a truth value of $58 \%$ after being compared with the actual production data. Based on the results, it is necessary to re-develop so that the accuracy results obtained are even greater, one way that can be done for the next researcher is to pay attention to the rules that are formed, especially when combined using order 0 and order 1.
\end{abstract}

Keywords : Fuzzy Logic, Fuzzy Sugeno Method, Rule, Random tree, Prediction 


\section{PENDAHULUAN}

Logika Fuzzy merupakan sebuah logika yang mempunyai nilai kesamaran (fuzzyness) antara salah atau benar [1], dimana logika fuzzy pertama kali dikenalkan oleh Lotfi Asker Zadeh melalui tulisannya pada tahun 1965 tentang teori himpunan fuzzy [2]. Banyak macam dan jenis dari logika fuzzy, diantaranya yaitu, fuzzy yang tergolong dalam jenis Fuzzy Inference System terdapat fuzzy Tsukamoto, Mamdani, dan Sugeno. Dalam penelitian ini yang akan dibahas adalah fuzzy Sugeno dengan menggunakan kombinasi rule yang dibangun menggunakan random tree. Alasan digunakannya metode fuzzy Sugeno karena aturan yang direpresentasikan dalam bentuk IF - THEN, dimana output (konsekuen) sistem tidak berupa himpunan fuzzy, melainkan berupa konstanta atau persamaan linear [3]. Data yang digunakan untuk mengetahui kinerja dari fuzzy Sugeno dalam penelitian ini diperoleh dari pengusaha kain tenun Mlaki Wanarejan Utara Pemalang, berupa jumlah produksi kain tenun, yang dipengaruhi oleh banyaknya biaya produksi, permintaan dari pelanggan, dan stok yang tersedia. Selanjutnya, data tersebut digunakan untuk membangun sebuah rule dengan menggunakan pohon keputusan random tree yang dieksekusi oleh tools WEKA [4]. Digunakannya random tree salah satunya untuk membuat rule secara otomatis dari data yang tersedia tanpa perlu berkonsultasi dengan pakar [5], selain itu untuk memperkenalkan random tree dalam bidang penelitian karena masih sedikitnya penelitian yang menggunakan pohon keputusan tersebut. Kerja dari pohon keputusan random tree adalah pohon yang dibangun secara acak [6] dari sekumpulan pohon yang mungkin memiliki fitur acak disetiap simpul (Mishra dan Ratha, 2016).

Berikut beberapa penelitian yang serupa yang peneliti ambil sebagai bahan dalam pembuatan penelitian ini. Pertama menurut [7] melakukan penelitian mengenai prediksi produksi minyak kelapa sawit dengan menggunakan metode fuzzy Tsukamoto, dimana rule yang dibangun menggunakan pohon keputusan J48 dan REPTree dengan kriteria yang ada yaitu, banyaknya kelapa sawit, permintaan, dan persediaan. Setelah dihitung diperoleh kesimpulan bahwa pohon keputusan REPTree memiliki nilai yang mendekati dari data produksi sesungguhnya dibandingkan dengan J48. Kedua menurut [8] melakukan penelitian mengenai prediksi produksi kain tenun dengan menggunakan metode fuzzy Tsukamoto dan Sugeno, dimana rule yang dibangun menggunakan pohon keputusan J48 dengan kriteria yang ada yaitu, banyaknya biaya produksi, permintaan, dan stok. Setelah dihitung diperoleh kesimpulan bahwa pohon keputusan metode fuzzy Tsukamoto memiliki nilai yang mendekati dari data produksi sesungguhnya dibandingkan dengan fuzzy Sugeno. Ketiga menurut [9] melakukan penelitian mengenai prediksi jumlah produksi palm oil dengan menggunakan metode fuzzy Mamdani, dimana rule yang dibangun dibantu oleh pakar dengan kriteria yang ada yaitu, jumlah penerimaan palm oil, jumlah persediaan palm oil dan jumlah permintaan palm oil. Setelah dihitung diperoleh kesimpulan bahwa Akurasi prediksi jumlah produksi palm oil menggunakan metode fuzzy mamdani cukup variatif dimana akurasi terendah adalah $16.14 \%$ dan tertinggi $73.41 \%$. Keempat menurut [10] mekakukan penelitian mengenai prediksi jumlah produksi barang dengan menggunakan metode fuzzy Mamdani, dimana rule yang dibangun dibantu oleh pakar dengan kriteria yang ada yaitu, jumlah permintaan dan jumlah persediaan. Setelah dihitung diperoleh kesimpulan bahwa hasil prediksi jumlah produksi barang dapat dikatakan layak, karena hasil prediksi dengan jumlah produksi sesungguhnya hampir mendekati. Kelima menurut [11] melakukan penelitian mengenai penerapan metode fuzzy Sugeno dalam diagnosa penyakit gigi, dimana rule yang dibangun dibantu oleh pakar dengan kriteria yang ada yaitu berbagai jenis sakit gigi. Setelah dihitung diperoleh kesimpulan bahwa hasil didapatkan ketepatan hasil tingkat keparahan diagnosa penyakit gigi sebesar $71,43 \%$.

Berdasarkan hal-hal yang telah dijelaskan di atas, pemodelan penelitian ini dilakukan dengan tujuan untuk mempercepat dalam membuat rule tanpa harus berkonsultasi terhadap pakar, dikarenakan rule yang terbentuk disertai akurasi, serta dibuktikan secara langsung dengan produksi sesungguhnya, selain itu untuk mengetahui kinerja fuzzy Sugeno dalam menangani kasus prediksi jumlah produksi kain tenun dengan menggunakan pohon keputusan random tree.

\section{METODE}

Metode penelitian yang digunakan dalam penelitian ini dapat dilihat pada Gambar 1.

\section{A. Dataset}

Dataset diperoleh di Mlaki Wanarejan Utara Pemalang dengan wawancara secara langsung kepada pihak kain tenun yaitu kepada Bu Nyai Diana selaku pemilik pengusaha kain tenun. Data yang diperoleh adalah data biaya produksi, permintaan, stok serta jumlah 
produksi. Adapun datanya dapat dilihat pada Tabel 1. Dataset.

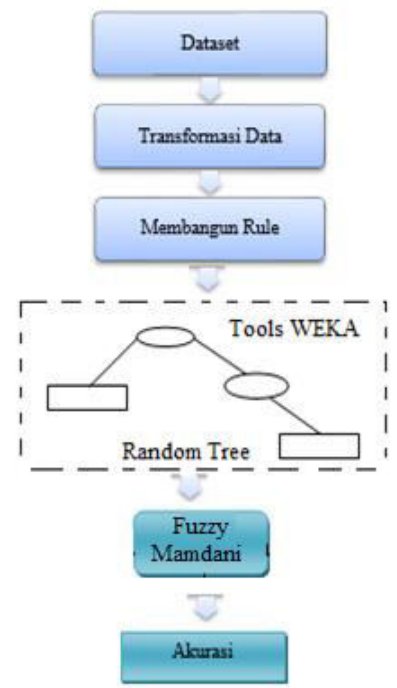

Gambar 1. Alur Penelitian

Tabel 1. Dataset

\begin{tabular}{|c|c|c|c|}
\hline Biaya produksi & Permintaan & Stok & $\begin{array}{c}\text { Jumlah } \\
\text { Produksi }\end{array}$ \\
\hline $\operatorname{Rp} 1.500 .000$ & 100 & 15 & 120 \\
\hline Rp 1.200 .000 & 110 & 12 & 128 \\
\hline Rp 1.000.000 & 200 & 50 & 205 \\
\hline Rp 1.100.000 & 300 & 75 & 305 \\
\hline Rp 1.600 .000 & 400 & 10 & 410 \\
\hline Rp 1.000.000 & 50 & 5 & 106 \\
\hline Rp 900.000 & 230 & 12 & 280 \\
\hline Rp 1.400 .000 & 124 & 100 & 180 \\
\hline Rp 900.000 & 450 & 100 & 465 \\
\hline Rp 1.100.000 & 105 & 98 & 250 \\
\hline Rp 1.600.000 & 290 & 230 & 100 \\
\hline Rp 1.000.000 & 50 & 10 & 100 \\
\hline Rp 900.000 & 50 & 15 & 80 \\
\hline Rp 1.400 .000 & 75 & 34 & 116 \\
\hline Rp 900.000 & 120 & 100 & 122 \\
\hline Rp 1.200 .000 & 126 & 59 & 160 \\
\hline Rp 7.890.400 & 220 & 33 & 224 \\
\hline Rp 8.806.250 & 245 & 24 & 250 \\
\hline $\operatorname{Rp} 14.547 .925$ & 409 & 65 & 413 \\
\hline $\operatorname{Rp} 10.497 .050$ & 292 & 22 & 298 \\
\hline Rp 7.608.600 & 211 & 32 & 216 \\
\hline $\operatorname{Rp} 12.082 .175$ & 340 & 58 & 343 \\
\hline Rp 7.925.625 & 215 & 27 & 225 \\
\hline $\operatorname{Rp} 16.344 .400$ & 485 & 64 & 464 \\
\hline $\operatorname{Rp} 16.600 .000$ & 450 & 40 & 472 \\
\hline Rp 8.806.250 & 245 & 38 & 250 \\
\hline Rp 8.665.350 & 243 & 26 & 246 \\
\hline Rp 8.348.325 & 300 & 30 & 237 \\
\hline $\operatorname{Rp} 10.664 .000$ & 242 & 37 & 248 \\
\hline $\operatorname{Rp} 12.900 .000$ & 276 & 44 & 300 \\
\hline Rp 6.000.000 & 320 & 60 & $?$ \\
\hline $\operatorname{Rp} 11.592 .000$ & 417 & 73 & ? \\
\hline
\end{tabular}

Tabel 1. Dataset

\begin{tabular}{cccc}
\hline Biaya produksi & Permintaan & Stok & $\begin{array}{c}\text { Jumlah } \\
\text { Produksi }\end{array}$ \\
\hline Rp 10.860.000 & 408 & 69 & $?$ \\
$\operatorname{Rp~} 14.090 .000$ & 446 & 95 & $?$ \\
$\operatorname{Rp~} 9.320 .000$ & 320 & 90 & $?$ \\
\hline
\end{tabular}

Dapat dilihat pada Tabel 1 pada bulan Maret 2020 sampai Juli 2020 belum diketahui jumlah produksi yang ada, sehingga data tersebut dipisahkan untuk dijadikan sebagai data uji yang terlihat pada Tabel 2. Data Uji.

Tabel 2. Data Uji

\begin{tabular}{lccc}
\hline Biaya produksi & Permintaan & Stok & $\begin{array}{c}\text { Jumlah } \\
\text { Produksi }\end{array}$ \\
\hline $\operatorname{Rp~} 6.000 .000$ & 320 & 60 & $?$ \\
$\operatorname{Rp~} 11.592 .000$ & 417 & 73 & $?$ \\
$\operatorname{Rp~} 10.860 .000$ & 408 & 69 & $?$ \\
$\operatorname{Rp~} 14.090 .000$ & 446 & 95 & $?$ \\
$\operatorname{Rp~} 9.320 .000$ & 320 & 90 & $?$ \\
\hline
\end{tabular}

\section{B. Transformasi Data}

Transformasi dilakukan untuk proses membangun rule yang terbentuk dengan menggunakan pohon keputusan random tree, kemudian dieksekusi oleh tools WEKA. Data yang dirubah kedalam transformasi adalah kriteria jumlah produksi, dimana dirubah kedalam bentuk himpunan fuzzy [12] yang terdiri dari banyak dan sedikit, terlihat pada Tabel 3. Transformasi Data.

Tabel 3. Transformasi Data

\begin{tabular}{|c|c|c|c|}
\hline Biaya produksi & Permintaan & Stok & $\begin{array}{l}\text { Jumlah } \\
\text { Produksi }\end{array}$ \\
\hline $\operatorname{Rp} 1.500 .000$ & 100 & 15 & Sedikit \\
\hline $\operatorname{Rp} 1.200 .000$ & 110 & 12 & Sedikit \\
\hline Rp 1.000.000 & 200 & 50 & Sedikit \\
\hline Rp 1.100.000 & 300 & 75 & Banyak \\
\hline $\operatorname{Rp} 1.600 .000$ & 400 & 10 & Banyak \\
\hline $\operatorname{Rp} 1.000 .000$ & 50 & 5 & Sedikit \\
\hline $\operatorname{Rp} 900.000$ & 230 & 12 & Banyak \\
\hline Rp 1.400.000 & 124 & 100 & Sedikit \\
\hline Rp 900.000 & 450 & 100 & Banyak \\
\hline Rp 1.100.000 & 105 & 98 & Sedikit \\
\hline Rp 1.600.000 & 290 & 230 & Sedikit \\
\hline Rp 1.000.000 & 50 & 10 & Sedikit \\
\hline $\operatorname{Rp} 900.000$ & 50 & 15 & Sedikit \\
\hline Rp 1.400.000 & 75 & 34 & Sedikit \\
\hline Rp 900.000 & 120 & 100 & Banyak \\
\hline $\operatorname{Rp} 1.200 .000$ & 126 & 59 & Sedikit \\
\hline Rp 7.890.400 & 220 & 33 & Sedikit \\
\hline Rp 8.806.250 & 245 & 24 & Sedikit \\
\hline Rp 14.547.925 & 409 & 65 & Banyak \\
\hline Rp 10.497.050 & 292 & 22 & Banyak \\
\hline Rp 7.608.600 & 211 & 32 & Sedikit \\
\hline Rp 12.082.175 & 340 & 58 & Banyak \\
\hline Rp 7.925.625 & 215 & 27 & Sedikit \\
\hline 1104 & & & \\
\hline
\end{tabular}


Tabel 3. Transformasi Data

\begin{tabular}{lccc}
\hline Biaya produksi & Permintaan & Stok & $\begin{array}{c}\text { Jumlah } \\
\text { Produksi }\end{array}$ \\
\hline Rp 16.600.000 & 450 & 40 & Banyak \\
Rp 8.806.250 & 245 & 38 & Sedikit \\
Rp 8.665.350 & 243 & 26 & Sedikit \\
Rp 8.348.325 & 300 & 30 & Sedikit \\
Rp 10.664.000 & 242 & 37 & Sedikit \\
Rp 12.900.000 & 276 & 44 & Banyak \\
\hline
\end{tabular}

\section{Membangun Rule}

Membuat rule berdasarkan decision random tree dengan menggunakan tools weka, dengan cara menggenerate semua data biaya produksi, permintaan, stok, dan jumlah produksi kemudian diproses dengan menghasilkan kontruksi pohon keputusan serta terbentuk aturan klasifikasi [13] dari data pada Tabel 3. Transformasi Data.

\section{Fuzzy Sugeno}

Penalaran dengan metode fuzzy Sugeno hampir sama dengan penalaran fuzzy Mamdani, hanya saja output (konsekuen) sistem tidak berupa himpunan fuzzy, melainkan berupa konstanta atau persamaan linear. Metode ini diperkenalkan oleh Takagi-Sugeno Kang pada tahun 1985

a. Model Fuzzy Sugeno Orde-Nol

Secara umum bentuk model fuzzy Sugeno Orde-Nol adalah:

IF $\left(x_{1}\right.$ is $\left.A_{1}\right) \cdot\left(x_{2}\right.$ is $\left.A_{2}\right) \cdot \ldots \ldots . .\left(x_{\mathrm{i}}\right.$ is $\left.A_{\mathrm{i}}\right)$

THEN $z=\mathrm{k}$

dengan $\mathrm{Ai}$ adalah himpunan fuzzy ke-i sebagai anteseden, dan $\mathrm{k}$ adalah satu konstanta (tegas) sebagai konsekuen.

b. Model Fuzzy Sugeno Orde-Satu

Secara umum bentuk model fuzzy Sugeno Orde-Satu adalah:

IF $\left(x_{1}\right.$ is $\left.A_{1}\right) \bullet\left(x_{2}\right.$ is $\left.A_{2}\right) \cdot \ldots \ldots . .\left(x_{\mathrm{i}}\right.$ is $\left.A_{\mathrm{i}}\right)$

THEN $z=p_{1}{ }^{*} x_{1}+\ldots . .+p_{i}{ }^{*} x_{i}+q$

dengan $\mathrm{Ai}$ adalah himpunan fuzzy ke-i sebagai anteseden, dan pi adalah suatu konstanta (tegas) ke-i dan q juga merupakan konstanta dalam konsekuen. Apabila komposisi aturan menggunakan metode fuzzy Sugeno, maka deffuzifikasi dilakukan dengan cara mencari nilai rataratanya.
Dalam mendapatkan output dengan menggunakan metode fuzzy Sugeno, diperlukan 3 tahapan yang harus dilakukan:

1. Pembentukan himpunan fuzzy

Dalam pembentukan himpunan fuzzy, maka diperlukan model aturan yang digunakan, baik dari segi domain, banyaknya himpunan fuzzy yang digunakan, dan representasi fungsi keanggotaan, yang terlihat pada Tabel 4. Model Aturan Himpunan Fuzzy dan Gambar 2. Fungsi Keanggotaan.

Tabel 4. Model Aturan Himpunan Fuzzy

\begin{tabular}{|c|c|c|c|}
\hline $\begin{array}{c}\text { Paramet } \\
\text { er }\end{array}$ & Kriteria & $\begin{array}{l}\text { Himpunan } \\
\text { Fuzzy }\end{array}$ & Domain \\
\hline \multirow{11}{*}{ Input } & \multirow{5}{*}{$\begin{array}{c}\text { Biaya } \\
\text { produksi }\end{array}$} & & Rp 9.000 .000 \\
\hline & & Sedikit & $\operatorname{Rp} 12 . \overline{800.000}$ \\
\hline & & & Rp 9.000 .000 \\
\hline & & Sedang & Rp $16 . \overline{6} 00.000$ \\
\hline & & Banyak & $\begin{array}{l}\mathrm{Rp} 12.800 .000 \\
\operatorname{Rp} 16.600 .000\end{array}$ \\
\hline & \multirow{3}{*}{$\underset{\mathrm{n}}{\text { Permintaa }}$} & Sedikit & $50-267,5$ \\
\hline & & Sedang & $50-485$ \\
\hline & & Banyak & $267,5-485$ \\
\hline & \multirow{3}{*}{ Stok } & Sedikit & $5-117,5$ \\
\hline & & Sedang & $5-230$ \\
\hline & & Banyak & $117,5-230$ \\
\hline \multirow{3}{*}{ Output } & \multirow{3}{*}{$\begin{array}{l}\text { Jumlah } \\
\text { Produksi }\end{array}$} & Sedikit & $80-276$ \\
\hline & & Sedang & $80-472$ \\
\hline & & Banyak & $276-472$ \\
\hline
\end{tabular}

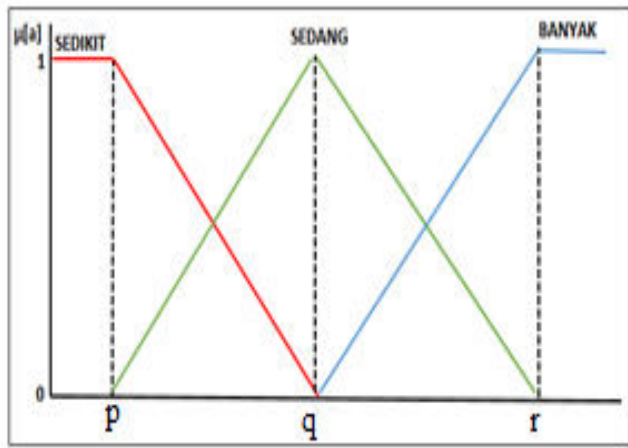

Gambar 2. Fungsi Keanggotaan

$$
\begin{gathered}
\mu_{[p](x)}\left\{\begin{array}{lr}
0 & x \geq q \\
\frac{q-x}{q-p}, & p \leq x \leq q \\
1 & x \leq p
\end{array}\right. \\
\mu[q](x)\left\{\begin{array}{cr}
0, x \leq p \text { atau } x \geq r \\
\frac{x-p}{q-p}, & p \leq x<q \\
\frac{r-x}{r-q}, & q<x \leq r \\
1 & x=q
\end{array}\right.
\end{gathered}
$$


2. Aplikasi Fungsi Implikasi

$$
\mu_{[r](\boldsymbol{x})}\left\{\begin{array}{lr}
0 & x \leq q \\
\frac{x-r}{r-q}, & q \leq x \leq r \\
1 & x \geq r
\end{array}\right.
$$

Pada metode fuzzy Sugeno, fungsi implikasi yang digunakan adalah Min [14], yang berbentuk if....then.... dengan menggunakan operasi AND.

$$
\mu A \cap B=\min (\mu A[x], \mu B[y])
$$

dengan:

$\mu \mathrm{A}[\mathrm{x}]=$ nilai derajat keanggotaan solusi fuzzy sampai aturan ke-i;

$\mu \mathrm{B}[\mathrm{y}]=$ nilai derajat keanggotaan konsekuen fuzzy aturan ke-i;

3. Penegasan (Deffuzy)

Input dari proses defuzzifikasi adalah suatu himpunan fuzzy yang diperoleh dari komposisi aturan-aturan fuzzy [15], sedangkan output yang dihasilkan merupakan suatu bilangan pada domain himpunan fuzzy tersebut. Sehingga jika diberikan suatu himpunan fuzzy dalam range tertentu, maka harus dapat diambil suatu nilai crsip tertentu sebagai output. Dalam metode fuzzy Sugeno, defuzzifikasi dilakukan dengan cara mencari nilai rata-rata terbobot (weight average). Secara umum dirumuskan:

$$
\mathrm{WA}=\frac{\sum_{i=1}^{n} a_{\mathrm{i}} z_{\mathrm{i}}}{\sum_{i=1}^{n} a_{\mathrm{i}}}
$$

\section{E. Akurasi}

Akurasi digunakan dengan metode error Average Forecasting Error Rate (AFER). Adapun perhitungannya adalah:

$$
\text { AFER }=\frac{\sum\left(\frac{\left|A_{i}-F_{i}\right|}{A_{i}}\right)}{n} \times 100 \%
$$

Dimana $A i$ adalah data sesungguhnya pada data dan $\mathrm{Fi}$ adalah nilai hasil prediksi untuk data ke-i. Adapun $\mathrm{n}$ adalah banyaknya data [16].

\section{Hasil dan Pembahasan}

\section{A. Implementasi WEKA Membuat Rule Random Tree}

Pembuatan rule untuk membangun pohon keputusan random tree dengan menggunakan implementasi WEKA. Hasil yang diperoleh terlihat pada Gambar 3. Pohon Keputusan Random Tree. Dari Gambar 3, dapat disimpulkan bahwa aturan yang terbentuk dari random tree diperoleh batasan datanya adalah sebagai berikut:

\section{Permintaan:}

Banyak: $\geq 261$

Sedang: $85-260$

Sedikit: $<85$

Stok:

Banyak: $\geq 165$

Sedang: $164-26$

Sedikit: $<26$

\section{Biaya Produksi:}

Banyak: $\geq \operatorname{Rp} 9.500 .000$

Sedikit: < Rp 9.500.000

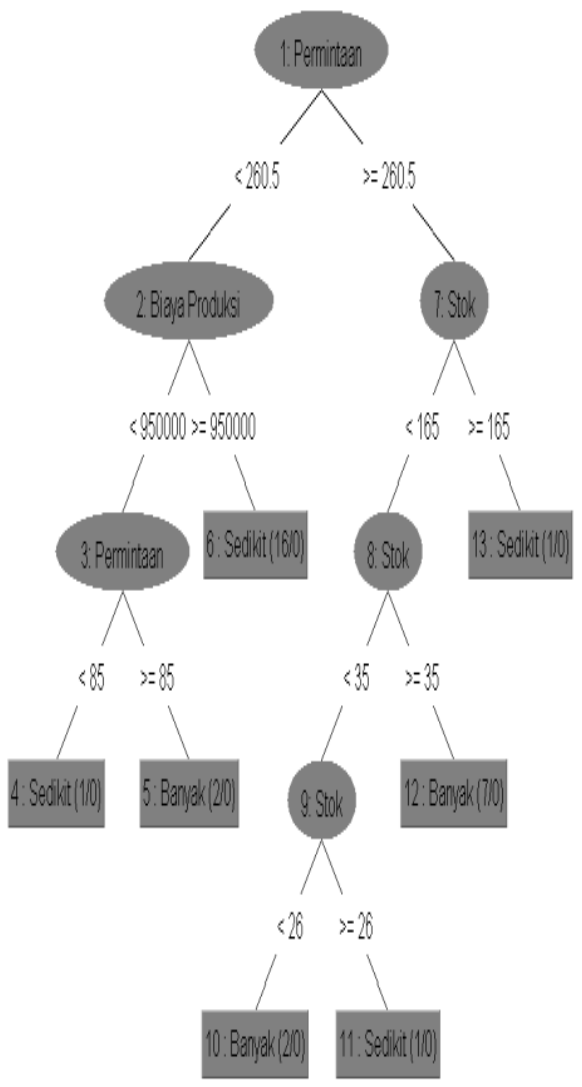

Gambar 3. Pohon Keputusan Random Tree

Berdasarkan batasan data di atas dan Gambar 2, sehingga didapatkan sebuah rule yang terlihat pada Tabel 5. Rule.

Tabel 5. Rule

\begin{tabular}{ll}
\hline Rule & Kondisi \\
\hline R1 & $\begin{array}{l}\text { IF Permintaan Sedikit THEN Jumlah } \\
\text { Produksi Sedikit }\end{array}$ \\
R2 & $\begin{array}{l}\text { IF Permintaan Sedang AND Biaya } \\
\text { Produksi Sedikit THEN Jumlah }\end{array}$ \\
R3 & $\begin{array}{l}\text { Produksi Banyak } \\
\text { IF Permintaan Sedang AND Biaya } \\
\text { Produksi Banyak THEN Jumlah }\end{array}$
\end{tabular}


Produksi Sedikit

R4 IF Permintaan Banyak AND Stok Sedikit THEN Jumlah Produksi Banyak

R5 IF Permintaan Banyak AND Stok Sedang THEN Jumlah Produksi Sedikit

R6 IF Permintaan Banyak AND Stok Sedang THEN Jumlah Produksi Banyak

R7 IF Permintaan Banyak AND Stok Banyak THEN Jumlah Produksi Sedikit

Hasil dari Tabel 5, secara detail baik dari akurasi pohon keputusan random tree yang terbentuk, akurasi untuk setiap kelas klasifikasi, bahkan nilai confusion matrix [17] yang diperoleh semua dapat terlihat pada Gambar 5. Classifer Output.

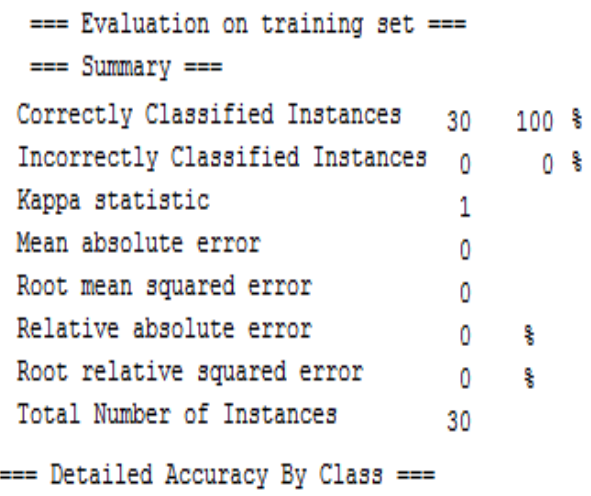

TP Rate FP Rate Precision Recall F-Measure ROC Area Class

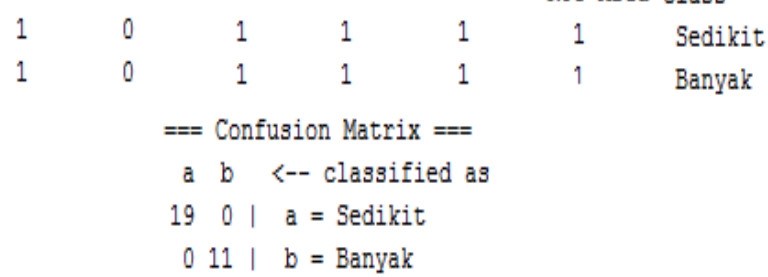

Gambar 4. Classifer output

Tabel 5. Rule, kemudian dikombinasikan dengan menggunakan orde 0 dan orde 1 agar tidak berupa himpunan fuzzy, melainkan berupa konstanta atau persamaan linear, dimana terlihat pada Tabel 6. Rule Kombinasi.

Tabel 6. Rule Kombinasi

\begin{tabular}{ll}
\hline Rule & Kondisi \\
\hline R1 & IF Permintaan Sedikit THEN Jumlah \\
& Produksi = Permintaan \\
R2 & $\begin{array}{l}\text { IF Permintaan Sedang AND Biaya } \\
\text { Produksi Sedikit THEN Jumlah }\end{array}$ \\
& $\begin{array}{l}\text { Produksi = Permintaan - Stok } \\
\text { R3 }\end{array}$
\end{tabular}

Produksi Banyak THEN Jumlah Produksi $=1,25 *$ Permintaan Stok

R4 IF Permintaan Banyak AND Stok Sedikit THEN Jumlah Produksi = Permintaan - Stok

R5 IF Permintaan Banyak AND Stok Sedang THEN Jumlah Produksi $=1,25$ * Permintaan - Stok

R6 IF Permintaan Banyak AND Stok Sedang THEN Jumlah Produksi $=1,20 *$ Permintaan - Stok

R7 IF Permintaan Banyak AND Stok Banyak THEN Jumlah Produksi = Permintaan

\section{B. Perhitungan Fuzzy Sugeno}

Berikut contoh perhitungan prediksi jumlah produksi manual dengan menggunakan fuzzy Sugeno berdasarkan pada Tabel 2. Data Uji, dimana yang akan dijadikan contoh perhitungan manualnya yaitu, pada besarnya biaya produksi sebesar Rp 6.000.000, permintaan sebesar 320 , dan stok yang ada sebanyak 60 .

\section{Langkah 1:}

Menentukan kriteria variabel yang terkait untuk proses fuzzifikasi.

1. Biaya produksi $(\mathrm{x})$, terdiri atas 3 himpunan fuzzy, yaitu SEDIKIT, SEDANG, dan BANYAK [18]. Berdasarkan dari Tabel 4, maka fungsi keanggotaan biaya produksi dirumuskan sebagai berikut:

$$
\begin{gathered}
\boldsymbol{\mu}_{\text {biayaprod-sedikit }[\boldsymbol{x}]}: \\
\left\{\begin{array}{cc}
0, & x \geq 12.800 .000 \\
\frac{12.800 .000-x}{3.800 .000}, & 9.000 .000 \leq x \leq 12.800 .000 \\
1, & x \leq 9.000 .000
\end{array}\right. \\
\boldsymbol{\mu}_{\text {biayaprod-sedang }[x]}: \\
\left\{\begin{array}{cc}
\frac{x-9.000 .000}{3.800 .000}, & 9.000 .000 \leq x<12.800 .000 \\
\frac{16.600 .000-x}{3.800 .000}, & 12.800 .000<x \leq 16.600 .000 \\
1, & x=12.800 .000
\end{array}\right.
\end{gathered}
$$

$\mu_{\text {biayaprod-banyak }[x]}$ : 


$$
\left\{\begin{array}{cc}
0 & x \leq 12.800 .000 \\
\frac{x-12.800 .000}{3.800 .000}, & 12.800 .000 \leq x \leq 16.600 .000 \\
1 & x \geq 16.600 .000
\end{array}\right.
$$

2. Permintaan $(y)$, terdiri atas 3 himpunan fuzzy, yaitu SEDIKIT, SEDANG, dan BANYAK. Berdasarkan dari Tabel 4, maka fungsi keanggotaan permintaan dirumuskan sebagai berikut:

$$
\begin{aligned}
& \mu_{\text {permintaan-sedikit }[y]} \text { : } \\
& \left\{\begin{array}{cc}
0, & y \geq 267,5 \\
\frac{267,5-y}{217,5}, & 50 \leq y \leq 267,5 \\
1, & y \leq 50
\end{array}\right. \\
& \mu_{\text {permintaan-sedang }[y]} \text { : } \\
& \left\{\begin{array}{cc}
0, y \leq 50 \text { atau } y \geq 485 \\
\frac{y-50}{217,5}, & 50 \leq y<267,5 \\
\frac{485-y}{217,5}, & 267,5<y \leq 485 \\
1, & y=267,5
\end{array}\right. \\
& \boldsymbol{\mu}_{\text {permintaan-banyak }[y]} \text { : } \\
& \left\{\begin{array}{ccrl}
0 & y & \leq 267,5 \\
\frac{y-267,5}{217,5}, & 267,5 & \leq y \leq 485 \\
1 & y & \geq 485
\end{array}\right.
\end{aligned}
$$

3. Stok (w), terdiri atas 3 himpunan fuzzy, yaitu SEDIKIT, SEDANG, dan BANYAK. Berdasarkan dari Tabel 4, maka fungsi keanggotaan stok dirumuskan sebagai berikut:

$$
\begin{aligned}
& \mu_{\text {stok-sedikit }[w]} \text { : } \\
& \left\{\begin{array}{cc}
0, & w \geq 117,5 \\
\frac{117,5-w}{112,5}, & 5 \leq w \leq 117,5 \\
1, & w \leq 5
\end{array}\right. \\
& \mu_{\text {stok-sedang }[x]} \text { : }
\end{aligned}
$$

$$
\left\{\begin{array}{cc}
0, \quad w \leq 5 \text { atau } w \geq 230 \\
\frac{w-5}{112,5}, \quad 5 \leq w<117,5 \\
\frac{230-w}{112,5}, \quad 117,5<w \leq 230 \\
1, \quad w=117,5
\end{array}\right.
$$

$$
\mu_{\text {stok-banyak }[x]} \text { : }
$$

$$
\left\{\begin{array}{ccrl}
0 & w & \leq 117,5 \\
\frac{w-117,5}{112,5}, & 117,5 & \leq w \leq 230 \\
1 & w & \geq 230
\end{array}\right.
$$

4. Jumlah produksi (z), terdiri atas 3 himpunan fuzzy, yaitu SEDIKIT, SEDANG, dan BANYAK. Berdasarkan dari Tabel 4, maka fungsi keanggotaan jumlah produksi dirumuskan sebagai berikut:

$$
\mu_{\text {jumlahprod-sedikit }[z]} \text { : }
$$

$$
\left\{\begin{array}{cc}
0, & z \geq 276 \\
\frac{276-z}{196}, & 80 \leq z \leq 276 \\
1, & z \leq 80
\end{array}\right.
$$

$$
\boldsymbol{\mu}_{- \text {jumlahprod-sedang }[z]} \text { : }
$$$$
\left\{\begin{array}{cc}
0, z \leq 80 \text { atau } z \geq 472 \\
\frac{z-80}{196}, \quad 80 \leq z<276 \\
\frac{472-z}{196}, \quad 276<z \leq 472 \\
1, \quad z=276
\end{array}\right.
$$

$\mu_{\text {jumlahprod-banyak }[\mathrm{z}]}$ :

$$
\left\{\begin{array}{cc}
0 & z \leq 276 \\
\frac{z-276}{196}, & 276 \leq z \leq 472 \\
1 & z \geq 472
\end{array}\right.
$$

Jika diketahui besarnya biaya produksi sebesar $\mathrm{Rp} 6.000 .000$, permintaan sebesar 320 , dan stok yang ada sebanyak 60 , maka:

$$
\begin{aligned}
& \mu_{\text {biayaprod-sedikit }[6000000]}=1 \\
& \mu_{\text {biayaprod-sedang }[6000000]}=0 \\
& \mu_{\text {biayaprod-banyak }[6000000]}=0 \\
& \mu_{\text {permintaan-sedikit }[320]}=0 \\
& \mu_{\text {permintaan-sedang }[320]}=\frac{485-320}{217,5}=0,7586 \\
& \mu_{\text {permintaan-banyak }[320]}=\frac{320-267,5}{217,5}=0,2414 \\
& \mu_{\text {stok-sedikit }[60]}=\frac{117,5-60}{112,5}=0,5111 \\
& \mu_{\text {stok-sedang }[60]}=\frac{60-5}{112,5}=0,4889
\end{aligned}
$$




$$
\mu_{\text {stok-banyak }[60]}=0
$$

\section{Langkah 2:}

Aplikasi fungsi implikasi menggunakan fungsi MIN, pada setiap aturannya:

R1: IF Permintaan Sedikit THEN Jumlah Produksi $=$ Permintaan

$$
\begin{aligned}
\alpha_{- \text {predikat } 1} & =\mu_{\text {permintaan-sedikit }} \\
& =\left(\mu_{\text {permintaan-sedikit }}[320]\right) \\
& =0
\end{aligned}
$$

Sehingga didapatkan nilai $Z_{1}=$ Permintaan

$$
Z_{1}=320
$$

R2: IF Permintaan Sedang AND Biaya Produksi Sedikit THEN Jumlah Produksi = Permintaan - Stok

$\alpha_{- \text {pred } 2}=\mu_{\text {permintaan-sedng }} \cap \mu_{\text {biayaprod-sediit }}$ $=\min (0,7586 ; 1)=0,7586$

Nilai $Z_{2}=$ Permintaan - Stok

$$
Z_{2}=320-60=260
$$

R3: IF Permintaan Sedang AND Biaya Produksi Banyak THEN Jumlah Produksi $=1,25$ * Permintaan - Stok

$$
\begin{aligned}
\alpha_{- \text {pred } 3}= & \mu_{\text {permintaan-sedng }} \\
& \cap \mu_{\text {biayaprod-banyak }} \\
= & \min (0,7586 ; 0)=0
\end{aligned}
$$

Nilai $Z_{3}=1,25 *$ Permintaan - Stok

$$
Z_{3}=1,25 * 320-60=340
$$

R4: IF Permintaan Banyak AND Stok Sedikit THEN Jumlah Produksi = Permintaan Stok

$$
\begin{aligned}
\alpha_{- \text {pred } 4}= & \mu_{\text {permintaan-banyak }} \cap \mu_{\text {stok-sedikit }} \\
& =\min (0,2414 ; 0,5111)=0,2414 \\
\text { Nilai } Z_{4} & =\text { Permintaan }- \text { Stok } \\
Z_{4} & =320-60=260
\end{aligned}
$$

R5: IF Permintaan Banyak AND Stok Sedang THEN Jumlah Produksi $=1,25$ Permintaan - Stok

$$
\begin{aligned}
\alpha_{\text {-pred } 5}= & \mu_{\text {permintaan-banyak }} \cap \mu_{\text {stok-sedang }} \\
& =\min (0,2414 ; 0,4889)=0,2414
\end{aligned}
$$

Nilai $Z_{5}=1,25 *$ Permintaan - Stok

$$
Z_{5}=1,25 * 320-60=340
$$

R6: IF Permintaan Banyak AND Stok Sedang THEN Jumlah Produksi $=1,20$ * Permintaan - Stok

$$
\begin{aligned}
\alpha_{\text {-pred6 }}= & \mu_{\text {permintaan-banyak }} \cap \mu_{\text {stok-sedang }} \\
& =\min (0,2414 ; 0,4889)=0,2414
\end{aligned}
$$

Nilai $Z_{6}=1,20 *$ Permintaan - Stok

$$
Z_{6}=1,20 * 320-60=324
$$

R7: IF Permintaan Banyak AND Stok Banyak THEN Jumlah Produksi Permintaan

$$
\begin{array}{r}
\alpha_{- \text {pred } 7}=\mu_{\text {permintaan-banyak }} \cap \mu_{\text {stok-banyak }} \\
=\min (0,2414 ; 0)=0
\end{array}
$$$$
\text { Nilai } Z_{7}=\text { Permintaan }
$$

$$
Z_{7}=320
$$

\section{Langkah 3:}

Melakukan defuzzifikasi dengan menggunakan metode dengan cara mencari nilai rata-rata terbobot (weight average).

$$
\begin{gathered}
\text { WA }=\frac{a_{\mathrm{i}} z_{1}+a_{2} z_{2}+a_{3} z_{3} \ldots . a_{7} z_{7}}{a_{\mathrm{i}}+a_{2}+a_{3} \ldots . a_{7}} \\
W A=\frac{0 * 320+0,7586 * 260+\cdots .+0 * 320}{0+0,7586+\cdots .+0} \\
\text { WA }=\frac{420,2896}{1,4828} \approx 283
\end{gathered}
$$

Setelah dihitung keseluruhan dari data uji menghasilkan hasil prediksi, yang terlihat pada Tabel 6. Hasil Prediksi Data Uji.

Tabel 6. Hasil Prediksi Data Uji

\begin{tabular}{cccc}
\hline Biaya produksi & Permintaan & Stok & $\begin{array}{c}\text { Prediksi } \\
\text { Produksi }\end{array}$ \\
\hline Rp 6.000.000 & 320 & 60 & 283 \\
Rp 11.592.000 & 417 & 73 & 403 \\
Rp 10.860.000 & 408 & 69 & 394 \\
Rp 14.090.000 & 446 & 95 & 443 \\
Rp 9.320.000 & 320 & 90 & 254
\end{tabular}

Hasil prediksi dibandingkan secara langsung dengan produksi sesungguhnya, secara detail terlihat pada Tabel 7. Perbandingan Hasil Prediksi dan Gambar 7. Perbandingan Hasil Prediksi.

Tabel 7. Perbandingan Hasil Prediksi

\begin{tabular}{ccccc}
\hline Biaya produksi & $\begin{array}{c}\text { Permin } \\
\text { taan }\end{array}$ & $\begin{array}{c}\text { Stok } \\
\text { Produks } \\
\text { i (Riil) }\end{array}$ & $\begin{array}{c}\text { Prediksi } \\
\text { Produksi }\end{array}$ \\
\hline $\operatorname{Rp~} 6.000 .000$ & 320 & 60 & 312 & 283 \\
$\operatorname{Rp~11.592.000~}$ & 417 & 73 & 386 & 403 \\
$\operatorname{Rp~10.860.000~}$ & 408 & 69 & 352 & 394 \\
$\operatorname{Rp~14.090.000~}$ & 446 & 95 & 394 & 443 \\
$\operatorname{Rp~} 9.320 .000$ & 320 & 90 & 310 & 254 \\
\hline
\end{tabular}




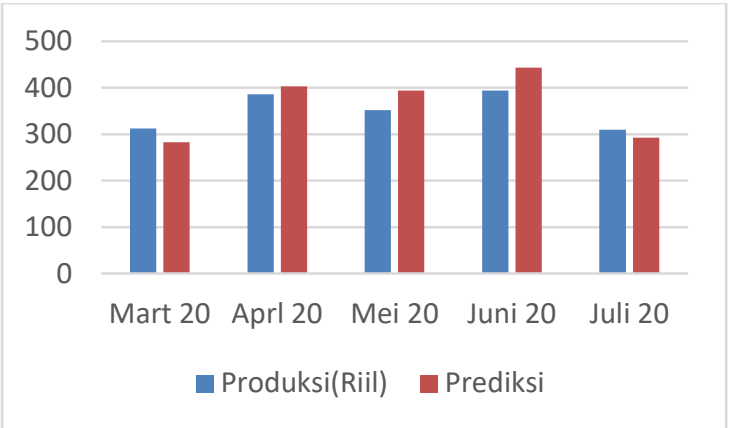

Gambar 5. Perbandingan Hasil Prediksi

\section{Analisis Hasil Perbandingan}

Analisis hasil perbandingan prediksi produksi pada Tabel 7 , diuji nilai erromya dengan menggunakan Average Forecasting Error Rate (AFER), didapatkan hasil akurasi yang terlihat pada Gambar 6.

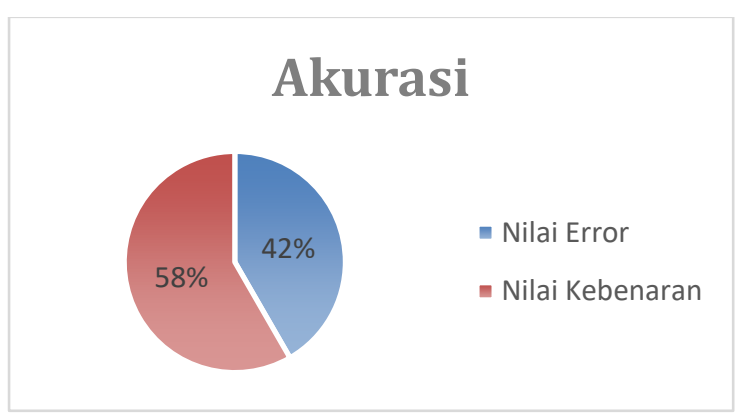

Gambar 6. Nilai Akurasi Prediksi

Berdasarkan Gambar 6. Nilai Akurasi Prediksi, bahwa warna merah merepresentasikan nilai error sebesar $42 \%$, warna biru merepresentasikan nilai kebenaran sebesar $58 \%$.

\section{KESIMPULAN}

Berdasarkan hasil penelitian mengenai kinerja fuzzy Sugeno dengan rule yang dibangun menggunakan pohon keputusan random tree dengan studi kasus produksi kain tenun di Mlaki Wanarejan Utara Pemalang, dapat diambil kesimpulan bahwa hasil prediksi yang diujikan memperoleh nilai Average Forecasting Error Rate (AFER) sebesar 42\% dengan nilai kebenaran $58 \%$ setelah dibandingkan dengan data produksi sesungguhnya. Berdasarkan hasil maka perlu dikembangkan kembali agar hasil akurasi yang didapatkan lebih besar lagi, salah satu cara yang dapat dilakukan untuk peneliti berikutnya adalah dengan memperhatikan rule yang terbentuk terutama pada saat dikbinasikan dengan menggunakan orde 0 dan orde 1 .

\section{DAFTAR PUSTAKA}

[1] S. Sivagowry and D. M, "An Intelligent
System based on Fuzzy Inference System to prophesy the brutality of Cardio Vascular Disease," Adv. Comput. Sci. an Int. J., vol. 4, no. 6, pp. 119-125, 2015.

[2] J. Hidayati, Sukardi, S. Ani, Sugiharto, and A. M. Fauzi, "Optimization of Business Partners Feasibility for Oil Palm Revitalization Using Fuzzy Approach," Int. J. Adv. Sci. Eng. Inf. Technol., vol. 3, no. 2, pp. 29-35, 2013.

[3] A. Bahroini, A. Farmadi, and R. A. Nugroho, "Prediksi Permintaan Produk Mie Instan Dengan Metode Fuzzy TakagiSugeno," Klik - Kumpul. J. IImu Komput., vol. 3, no. 2, p. 220, 2016.

[4] K. S. Elekar and M. M. Waghmare, "Study of Tree Base Data Mining Algorithms for Network Intrusion Detection," Int. J. Recent Innov. Trends Comput. Commun., vol. 2, no. 10, pp. 3253-3257, 2014.

[5] A. K. Hamoud, A. S. Hashim, and W. A. Awadh, "Predicting Student Performance in Higher Education Institutions Using Decision Tree Analysis," Int. J. Interact. Multimed. Artif. Intell., vol. 5, no. 2, p. 26, 2018.

[6] S. S. Alaoui, Y. Farhaoui, and B. Aksasse, "Classification Algorithms in Data Mining: A Survey," IJSRCSEIT, vol. 3, no. 1, pp. 349355, 2018.

[7] T. Tundo and S. 'Uyun, "Penerapan Decision Tree J48 dan Reptree dalam Menentukan Prediksi Produksi Minyak Kelapa Sawit menggunakan Metode Fuzzy Tsukamoto," J. Teknol. Inf. dan IImu Komput., vol. 7, no. 3, p. 483, 2020.

[8] Tundo, R. Akbar, and E. I. Sela, "Analisis Perbandingan Fuzzy Tsukamoto Dan Sugeno Dalam Menentukan Jumlah Produksi Kain Tenun Menggunakan Base Rule Decision Tree," J. Teknol. Inf. dan IImu Komput., vol. 7, no. 1, pp. 171-180, 2020.

[9] C. P. P. Maibang and A. M. Husein, "Prediksi Jumlah Produksi Palm Oil Menggunakan Fuzzy Inference System Mamdani," J. Teknol. dan IImu Komput. Prima, vol. 2, no. 2, p. 19, 2019.

[10] M. Djunaidi, "Penentuan Jumlah Produksi Dengan," J. Ilm. Tek. Insudtri, vol. 4, no. 2, pp. 95-104, 2005.

[11] L. Salisa Setiawati, I. Budiman, and O. Soesanto, "Penerapan Fuzzy Inference System Takagi-Sugeno-Kang pada Sistem Pakar Diagnosa Penyakit Gigi," J. IImu Komput., vol. 04, no. 01, pp. 1-10, 2016.

[12] T. A. Mujahid and E. I. Sela, "Analisis Perbandingan Rule Pakar dan Decision Tree J48 Dalam Menentukan Jumlah 
Produksi Kain Tenun Menggunakan Metode Fuzzy Tsukamoto," JURIKOM (Jurnal Ris. Komputer), vol. 6, no. 5, pp. 501-505, 2019.

[13] Tundo, "PREDIKSI PRODUKSI MINYAK KELAPA SAWIT MENGGUNAKAN METODE FUZZY TSUKAMOTO DENGAN RULE YANG TERBENTUK MENGGUNAKAN DECISION TREE REPTREE," JANAPATI, vol. 9, no. 2, pp. 253-265, 2020.

[14] S. Batubara, "Analisis Perbandingan Metode Fuzzy Mamdani Dan Fuzzy Sugeno Untuk Penentuan Kualitas Cor Beton Instan," It J. Res. Dev., vol. 2, no. 1, pp. 1-11, 2017.

[15] D. Kartika, R. Sovia, and H. M. Sandawa, "Penerapan Metode Fuzzy Mamdani Untuk Memprediksi Angka Penjualan Token
Berdasarkan Persediaan Dan Jumlah," J. KomTekInfo, vol. 5, no. 1, pp. 81-95, 2018.

[16] T. M. Tuan et al., "M-CFIS-R: Mamdani complex fuzzy inference system with rule reduction using complex fuzzy measures in granular computing," Mathematics, vol. 8, no. 5, 2020.

[17] Tundo and E. I. Sela, "APPLICATION OF THE FUZZY INFERENCE SYSTEM METHOD TO PREDICT," Int. J. Informatics Dev., vol. 7, no. 1, pp. 1-9, 2018.

[18] S. D. P. Mustika Sari, H. Ginardi, and C. Fatichah, "Penentuan Harga dengan Menggunakan Sistem Inferensi Fuzzy Tsukamoto Pada Rancang Bangun Aplikasi 'Finding-Tutor,"' J. Tek. ITS, vol. 6, no. 2, 2017. 